\title{
An application of the SERVQUAL model to study the quality perceived by customers in a pizzeria
}

Lucas Oliveira dos Santos ${ }^{1}$, Federal University of Sergipe, Sergipe, Aracaju, Brazil

Emerson Cleister Lima Muniz², Federal University of Sergipe, Sergipe, Aracaju, Brazil

Emily Nadine Pereira ${ }^{3}$, Federal University of Sergipe, Sergipe, Aracaju, Brazil

Gertrudes Aparecida Dandolini ${ }^{4}$, Federal University of Santa Catarina, Santa Catarina, Brazil

João Artur de Souza ${ }^{5}$, Federal University of Santa Catarina, Santa Catarina, Brazil

\section{RESUMO}

Objetivo - Propor um conjunto de ações para melhoria dos serviços prestados por uma empresa do setor de alimentos mediante adaptação e aplicação do modelo SERVQUAL.

Desenho / metodologia / abordagem - A pesquisa aplica uma survey para coleta de dados e informações sobre o objeto em análise mediante aplicação de questionários junto a clientes da empresa. Para isto definiu-se a população e amostra ideal a ser alcançada pelo método de Amostra Aleatória Simples considerando erro amostral de 5\% e confiabilidade de $95 \%$.

Resultados - Os resultados apontem para uma avaliação geral negativa em todas as cinco dimensões da qualidade analisadas, destacando que dos 23 itens analisados pela pesquisa apenas 17,4\% deles apresentam resultados positivos na análise relacional entre expectativa e percepção frente a $82,6 \%$ que não atendem.

Originalidade/Valor - A análise minuciosa realizada por este trabalho, deu aos empresários uma visão mais detalhada da situação real do estabelecimento, indicando os pontos que demandavam melhorias emergenciais e que impactavam diretamente na avaliação negativa obtida pelo estabelecimento. Como mudanças imediatas identificadas, destaca-se a necessidade de criação de um melhor plano de marketing, localização da empresa e urgência em melhorar sua segurança. Palavras-chave: Serviços de alimentação. Qualidade nos serviços. Servqual. Análise de satisfação. Pizzarias.

\section{ABSTRACT}

Purpose - To propose a set of measures to improve the services provided by a company in the food sector by adapting and applying the SERVQUAL model.

Design/methodology/approach - This study uses a survey to collect data and information about the object being analyzed by giving questionnaires to the company's customers. For this, the population was defined along with the ideal sample to be achieved using the Simple Random Sampling method, considering a 5\% sampling error and 95\% reliability.

Findings - The findings indicate a negative general evaluation in all five dimensions of quality analyzed, highlighting that only $17.4 \%$ of the 23 items analyzed in the study had positive results in the relational analysis between expectation and perception compared to the $82.6 \%$ that do not present this.

Originality/Value - The in-depth analysis carried out in this study gave entrepreneurs a more detailed view of the actual state of the establishment, indicating the points that need to be improved urgently and that have directly affected the negative evaluation obtained by the establishment. The need to set up a better marketing plan, a change to the location of the establishment, and the urgent improvement of safety, were highlighted as items identified that need immediate change.

Keywords: Food services. Quality in services. SERVQUAL. Satisfaction analysis. Pizzerias.

1. lucasoliveira2516@gmail.com, https://orcid.org/0000-0002-4862-9612; 2. Avenida Quirino, 1020. Cond. Recanto dos Guaras, Bloco 02, Apt 102, Inácio Barbosa, Aracaju - SE, CEP: 49040-700, Brasil, eng.prod.emerson@gmail.com; https://orcid.org/0000-0002-9233-0618; 3. emily.nadine.ufs@gmail.com, https://orcid.org/0000-0002-3663-5468; 4. gertrudes.dandolini@ufsc.br, https://orcid.org/0000-0003-0867-9495; 5. jartur@gmail.com, https://orcid.org0000-0002-7133-8944

SANTOS, L.O.; MUNIZ, E.C.L.; PEREIRA, E.N.; DANDOLINI, G.A.; SOUZA, J.A. An application of the SERVQUAL model to study the quality perceived by customers in a pizzeria GEPROS. Gestão da Produção, Operações e Sistemas, v.16, nº 1, p. 01 - 22, 2021.

DOI: $\underline{\text { http://dx.doi.org/10.15675/gepros.v16i1.2339 }}$ 


\section{INTRODUCTION}

With the advance of globalization, companies have become driven to constant competition, and with this the search for differentiation has become a fundamental factor for them to stand out in the market (GONÇALVES; BELDERRAIN, 2012). In this market, services are elements present in the experience of each citizen. For example, transportation, food and health have been gaining increasing importance in the national scenario, highlighting the need to study the particularities of their operations (OLIVEIRA; FERREIRA, 2008).

According to the 2015 Annual Report of the Brazilian Association of Food Industries (ABIA), in that year the turnover of the food industry was around $\mathrm{R} \$ 561.9$ billion, distributed into $80.5 \%$ in food and $19.5 \%$ in beverages. In addition, the sector counted about 1.6 million direct jobs, representing its great importance for the country's economy.

According to data made available by the Brazilian Institute of Geography and Statistics (IBGE), the service sector was responsible for a share of $68.7 \%$ of the Gross Domestic Product (GDP) in 2012, characterizing it as the sector of greatest growth in that year.

Within the service sector, the food sector, which can be understood as preparing food outside the customers' homes, stands out (MOURA; ALLIPRANDINI, 2004). According to the ABIA, these services can be divided into two groups: public or institutional, which involve channels linked to the government, and private services provided by bars, restaurants, pizzerias, fast-food chains, among others.

In this scenario, pizzerias are highlighted in the food sector, as pizza has become one of the most popular foods in the world (SEBRAE, 2016). And pizzerias are considered a mixture of industry, commerce, and services, as they transform their main inputs into pizzas, sell beverages, and offer services to the customer such as home delivery (SEBRAE, 2016).

In this context, the quality of these services is something that has been widely discussed and, to understand the behavior of consumers, many researchers work on the elaboration of techniques and models to measure quality in services (SCHNEIDER; WHITE, 2004). One of the main tools used in this scenario is SERVQUAL, which seeks to measure the expectations and perceptions of customers and allows the proposition and implementation of improvements through the analysis of the data collected (PARASURAMAN et al., 1985). That said, this research aims to propose a set of actions focused on improving the services 
provided by a pizzeria, based on statistical analysis of the results obtained through the adaptation and application of the SERVQUAL model.

\section{THEORETICAL FOUNDATION}

\subsection{Food Services and their Quality}

A service can be considered a perishable, intangible experience, developed for a customer who plays the role of co-producer (FITZSIMMONS; FITZSIMMONS, 2005). It is an activity that generates value and brings benefits to both users and those who sell them. This benefit is associated with its execution, because when it is well performed it ends up generating benefits for consumers (LOVELOCK; WRIGHT, 2002). It is known that there are some exclusive characteristics that make services different from products and Gianesi and Corrêa (2004) highlight intangibility, customer participation, and simultaneous production and consumption as the main ones. With regard to the quality of services, Parasuraman et al. (1985) defines that it is based on specific dimensions, highlighting Reliability, Responsiveness, Assurance, Empathy, and Tangible Aspects.

As for food services, the Brazilian National Health Surveillance Agency (ANVISA, 2004) states that food services are establishments where food is handled, prepared, stored, and/or exposed for sale, whether it can be consumed on the spot. These services are extremely important for social interaction, given that the practice of eating food is rarely done by one person alone. And the act of eating something accompanied by drinks is usually a group action where people get together to enjoy pleasant moments together (SCLÜTER, 2003).

One of the biggest concerns of companies is to achieve outstanding numbers and obtain customer satisfaction when serving increasingly safe food, observing factors such as quality of raw material and preservation of food temperature to avoid food infections, for example (FIGUEIREDO; COSTA NETO, 2001). The production of safe food has grown in importance along with the new industrialization processes and the new trends in consumer behavior (SPERS, 2003). In addition, hygiene is also an aspect that is interconnected with food handling, since it must be processed with all the correct procedures (RICHARDS, 2005). In this way, companies have invested in new technological means to offer the customer foods with an excellent amount of nutrients and low caloric content that meet their needs and requirements (MONTEIRO, 2005). 
One of the ways to analyze the quality of a food product is through the subjective perspective of the consumer related to the human senses, in which the client analyzes, for example, elements related to characteristics such as taste, texture, shape, among others (SANTOS; ANTONELLI, 2011; SCALCO; TOLEDO, 2002). However, it is important to emphasize that the responsibility for the careful handling of food is entirely of the companies that produce it.

With this, these organizations can focus on the dimensions of quality aimed at food service to satisfy their customers. Some authors make adaptations of the quality dimensions in relation to the service being offered, which are very subjective and vary from author to author. Thus, this work was based on the dimensions of services for the food sector present in Wilson et al. (2012) and exposed in Table 1.

Table 1 - Food quality dimensions

\begin{tabular}{|c|l|}
\hline Dimensions & \multicolumn{1}{c|}{ Description } \\
\hline Tangibility & $\begin{array}{l}\text { This dimension can be understood as the appearance of the physical facilities, instruments } \\
\text { used, silverware, dishware, employees' uniforms, and hygiene of the place, organization, } \\
\text { characteristic, appearance, and state of conservation of menu charts, among other aspects. }\end{array}$ \\
\hline Responsiveness & $\begin{array}{l}\text { This dimension is related to the willingness and desire to help customers and provide a service } \\
\text { with agility. It also refers to the ability to clear up doubts and correct mistakes arising from } \\
\text { customer complaints in an efficient manner, always paying attention to consumers. }\end{array}$ \\
\hline Reliability & $\begin{array}{l}\text { It is the ability to deliver the service as promised, error-free. For pizzerias, it can be related to } \\
\text { the fact that, after the purchase and consumption, the product does not present divergences and } \\
\text { modifications in relation to taste, texture, odor, and temperature, that is, the pizza did not } \\
\text { present flaws in relation to what was specified on the menu. }\end{array}$ \\
\hline Assurance & $\begin{array}{l}\text { It is the knowledge and courtesy of the employees in relation to the service that is being } \\
\text { offered. For pizzerias, it is the knowledge about the ingredients of pizza flavors. This } \\
\text { dimension is associated to the employees who deal directly with customers. }\end{array}$ \\
\hline Empathy & $\begin{array}{l}\text { It is the diligent, careful, and individualized attention that the company offers to its customers. } \\
\text { In pizzerias, actions such as seeking to know the name of the customer, their preferences of } \\
\text { flavors, and their needs should be practiced. This can guarantee the customer's loyalty, and the } \\
\text { employees will know which are the most frequent orders, the personalization in the food, } \\
\text { preferred place in the establishment, and form of treatment. }\end{array}$ \\
\hline
\end{tabular}

Source: Adapted from Wilson et al. (2012).

It is noted then that meeting the dimensions of the services present in Table 1 can be a competitive differential of companies against their competitors, because they will ensure customer assurance and satisfaction. 


\subsection{The five gaps and the SERVQUAL instrument}

Initially, Parasuraman et al. (1985) structured five different types of gaps between what is delivered to customers and what they receive. Thus, the first gap relates the difference between customer expectations and the perception of managers, resulting from an inadequate understanding on the part of managers about how users form their expectations (PARASURAMAN et al., 1985).

Gap 2 is the difference between the managerial perception of customer expectations and the quality specifications of the service provided (PARASURAMAN et al., 1985). Gap 3 refers to possible mistakes that employees may make while performing the service, while Gap 4 occurs when companies do not deliver the service that was promised in advertisements or other communication vehicles, that is, it is the gap between the provision of the service and external communication to customers (PARASURAMAN et al., 1985).

Gap 5 is the one between service expectation and perception, resulting from the previous gaps and occurring when one or more previous gaps occur (PARASURAMAN et al., 1985). In view of this, the SERVQUAL model uses Gap 5 in Figure 1 to assess the quality perceived by customers in relation to the provision of services offered. And through 22 items posted in a questionnaire, it analyzes criteria related to five specific dimensions of services, namely Reliability, Readiness, Security, Empathy, and Tangibility.

So, SERVQUAL captures customer expectations and perceptions for each item using a 7-Point Likert Scale. On this scale, respondents position themselves according to a measure of agreement assigned to the item analyzed, whose extremes represent "I Totally Disagree" and "I Totally Agree". Values 2, 3, 4, 5, and 6 represent, in order, "I strongly disagree", "I partially disagree", "Neutral", "I partially agree", and "I strongly agree" (LIKERT, 1932). With this, the model can be used by different service companies, from the most diverse segments of activity, with adaptations in their question structure for the specific service under analysis (LIKERT, 1932).

\section{METHODOLOGICAL PROCEDURES}

\subsection{Characterization of the Research}

As for its nature, this research is classified as applied because it seeks to generate knowledge about the perceptions and expectations of the users of the analyzed service, and 
through the results achieved it seeks to propose solutions for the service offered (GIL, 2002); and as exploratory because it provides more information on the topic being studied and its relevant analysis relationships (CERVO et al., 2007).

Regarding the approach, this research can be classified both with a qualitative and quantitative bias. The first is justified using interpretation to gain access to the knowledge of customers' opinions about the services they receive from the pizzeria. It is quantitative because it seeks to identify and measure in a more analytical way the behavior of the public of the pizzeria, which, in turn, allows the inference of more concise results and based on the statistical analyzes carried out (FILHO, 2009).

In summary, the qualitative and quantitative approaches were used mainly because they allow checking the relationship between what is offered by the object of study and what is expected by its customers, enabling the researcher to reach several views of an analysis in addition to using treatment of data with statistical techniques to further improve these discussions (GIL, 2010).

As for technical procedures, this work can be seen as a survey, because, as Turrioni and Melo (2012) justify, in this type of research the collection of data and information on the object to be known and analyzed occurs directly with the people involved with it. In addition, it is also justified as a survey by the fact that it makes use of questionnaires to obtain the main data from the customers of the object under study, which are usually employed in surveys of this type.

\subsection{Population and Sampling}

The population of this research was defined by the average number of customers that visit the pizzeria per day, representing a total of approximately 160 customers. The sampling was defined by the method of Simple Random Sample proposed by Barbetta (2008) according to Equation 1. For the research, a sampling error of 5\% and reliability of $95 \%$ was considered, obtaining an ideal sample of 114 responses, being achieved a total of 105 valid at the end of the collection, that is, $92.1 \%$ of the projected ideal sample.

$$
n=\frac{\mathrm{N} \cdot \frac{1}{E_{0}^{2}}}{\mathrm{~N}+\frac{1}{E_{0}^{2}}}
$$

Where: 
$n=$ Number of elements of the sample;

$N=$ Number of elements of the population;

$E_{0}=$ Degree of sampling error.

So,

$n=\frac{160 \cdot \frac{1}{0.05^{2}}}{160+\frac{1}{0.05^{2}}} \cong 114$

The collection of samples was for accessibility, where customers were interviewed for using the services of the pizzeria and accessible to answer the survey at the time of its application. To avoid that the same client answered the questionnaires again, the context and objective of the survey was explained before the application and they were asked if they had answered before. This measure ensured that there was no more than one questionnaire answered by the same client.

It is important to emphasize that the survey questionnaire focused on the analysis of customer expectations was applied before the products were consumed in the pizzeria, and after consumption they were asked to answer the questionnaire focused on analyzing the perception of the services provided. Figure 1 presents the steps followed in this research.

Figure 1 - Steps of methodological procedures

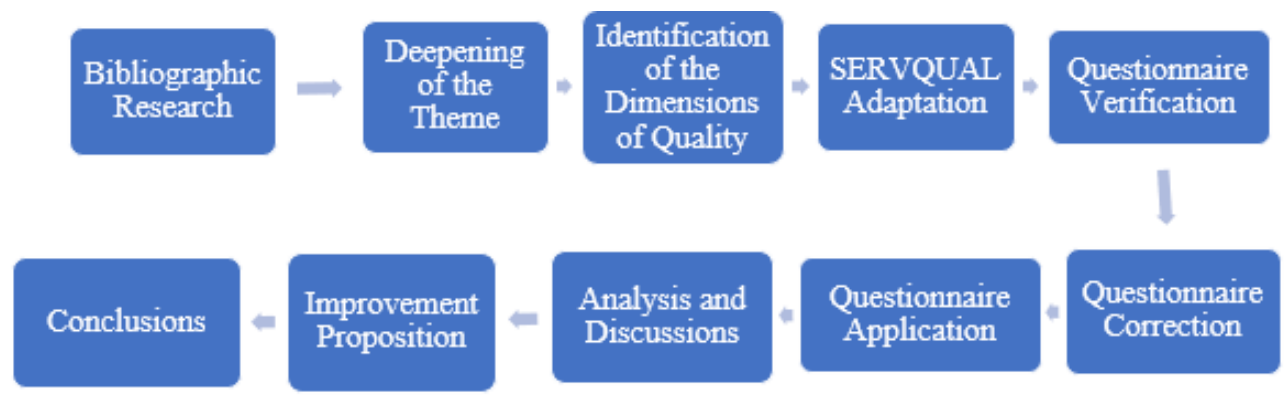

Source: Prepared by the authors.

The first step of the work consisted of a bibliographic search in the main national and international journals, as well as dissertations and books that address the themes related to services, their dimensions, their quality, the SERVQUAL model and its structure, in addition to points pertinent to food services. In sequence, the dimensions for the food service were identified and SERVQUAL was adapted to better suit the purpose of this work. During this change, the form of scale or assessment was not changed, that is, the self-filling characteristic 
and the use of the Likert scale to assess each item contained in the questionnaire were maintained.

The verification of the questionnaires or pre-test step was carried out by applying questionnaires to customers who attended the establishment. The purpose of the verification was to analyze whether there was a need to change the questions, in case of customer doubts, ambiguous ideas or changes in the amplitude of the Likert scale. In view of the pre-test, it was decided not to reformulate the questionnaire.

After these steps, the questionnaire was applied during one month in the pizzeria, based on the values of the Likert scale ranging from "1" to "7", where "1" represents "Low Agreement" and "7" "High Agreement". After applying the SERVQUAL, the collected data were tabulated using Microsoft Corporation's Excel ${ }^{\circledR}$ software so that they could be analyzed in order to develop a scenario of the current state of the process and, therefore, propose improvements in the service under analysis. With the analysis and discussion of the data it was possible to complete the work, interpreting them and offering solutions to the weaknesses of the services provided by the company.

It is important to point out that the research was applied to a pizzeria that had been in the market for approximately three years and is located in a middle-class area of the city of Aracaju, state of Sergipe, Brazil. The focus of the company is to serve clients of all social classes, combining quality service with affordable prices. The organization had six employees distributed into the functions of receptionists, telephone operators, pizza chefs, and waiters, and there was no organized and structured division in the management of the business, leaving it under the responsibility of the owner.

\section{RESULTS AND DISCUSSIONS}

\subsection{Reliability and profile of respondents}

In order to check the reliability of each dimension of the questionnaire, it was chose to use Cronbach's alpha coefficient. This, with $\alpha \in[0.1]$, is estimated from the variance of the individual criteria and the covariances between them. In this context, the alpha results applied to the dimensions were analyzed based on the classification by Malhotra (2008) shown in Table 2. 
Table 2 - Reliability Classification from the Cronbach's $\alpha$

\begin{tabular}{c|ccccc}
\hline Reliability & Very Low & Low & Moderate & High & Very High \\
\hline Value of $\alpha$ & $\alpha<0,30$ & $0,30 \leq \alpha \leq 0,60$ & $0,60 \leq \alpha \leq 0,75$ & $0,75 \leq \alpha \leq 0,90$ & $\alpha \geq 0,90$ \\
\hline
\end{tabular}

Source: Malhotra (2008).

From Table 2, the classes with a value of $\alpha>0.60$ are considered satisfactory. However, higher alpha values may indicate even better reliability degrees and the decision regarding the minimum reliability value of a questionnaire is up to the researcher. Table 3 shows the results obtained from this analysis.

Table 3 - Reliability analysis between the dimensions of the questionnaire

\begin{tabular}{|c|c|c|c|c|c|}
\hline & \multicolumn{5}{|c|}{ Dimensions } \\
\cline { 2 - 6 } & Tangibility & Reliability & Responsiveness & Assurance & Empathy \\
\hline $\boldsymbol{\alpha}$ for Expectation & 0,62 & 0,55 & 0,76 & 0,73 & 0,64 \\
\hline $\boldsymbol{\alpha}$ for Perception & 0,60 & 0,30 & 0,84 & 0,86 & 0,66 \\
\hline
\end{tabular}

Source: Prepared by the authors.

It is verified that only the Reliability dimension presented low values for the coefficient under analysis. However, because it has only two evaluation items and because it is considered important for the development of the study, it was decided to maintain the dimension, with the objective of making a qualitative analysis of the items that compose it and because they are considered extremely important for providing a pizzeria service. Then, the survey outlined the respondents' profiles to better understand the pizzeria's customers, as shown in Table 4.

Table 4 - Socioeconomic data of respondents

\begin{tabular}{ccc}
\hline Respondents profile & $\%$ & Total (\%) \\
\hline Gender & & \\
Male & 55,24 & 100 \\
Female & 44,76 & \\
\hline Age Range & $\%$ & \\
18 to 30 years & 60,95 & \\
31 to 40 years & 23,81 & 100 \\
41 to 50 years & 12,38 & \\
Above 51 years & 2,86 & \\
Family Income & $\%$ & \\
Up to 1 minimum wage & $8,57 \%$ & \\
From 1 to 4 minimum wages & $55,24 \%$ & 100 \\
From 4 to 8 minimum wages & $29,52 \%$ & \\
Above 8 minimum wages & $6,67 \%$ & \\
\hline
\end{tabular}

Source: Prepared by the authors.

Above 8 minimum wages $\quad 6,67 \%$

From Table 4 it can be seen that $55.24 \%$ of the interviewed are male, $60.95 \%$ are in the range of 18 to 30 years old, and $55.24 \%$ have family income from 1 to 4 minimum wages. 
One of the factors that explain the high percentage of young people that go to the pizzeria is the fact that it offers the rotation service (all-you-can-eat pizza), which attracts people of this age group.

Regarding gender, there is a balance between male and female people, allowing affirming that the predilection for pizza does not have an adherence to one of the sexes.

In relation to family income, the predominance of the range from 1 to 4 minimum wages may be related to the location of the pizzeria in a middle-class neighborhood, away from the neighborhoods where people with greater acquisitive power are concentrated.

\subsection{Analysis of the quality of services}

The results obtained from the application of the questionnaires were tabulated and statistically analyzed in terms of perception and expectation, and Table 5 presents the Average Expectation $(\bar{E})$, Average Perception $(\bar{P})$, Average Gap $(\bar{G})$, and Standard Deviation for each criterion addressed in the questionnaire. The Average Gap is the result of the subtraction between average perception and expectation and if the result of this operation is negative, the item is considered critical and needs improvement. When positive, expectations are exceeded and, when zero, expectations are equal to perceptions. In the last two cases, it can be said that the company meets the requirements for the service provided.

For a better detailing of the calculation memory, Equation 2 shows the formula used to calculate the values of the gaps and a demonstration for the Tangibility dimension.

$$
\text { Gap }=P-E
$$

Where:

Gap $=$ Service evaluation;

$P=$ Customers' perception of actual performance;

$E=$ Customers' expectations.

The gap for the calculated Tangibility dimension was negative $(-0.57)$ because the average perception was 5.94 and the average expectation was 6.51, and their subtraction generated this result. 
Table 5 - Dimensions and items obtained from the questionnaire analysis

\begin{tabular}{|c|c|c|c|c|c|}
\hline Dimensions and items & $\begin{array}{l}\text { Perception } \\
\qquad \bar{P}\end{array}$ & $\begin{array}{l}\text { Standard } \\
\text { Deviation } \\
\quad \text { of } \bar{P}\end{array}$ & $\begin{array}{l}\text { Expectation } \\
\qquad \bar{E}\end{array}$ & $\begin{array}{l}\text { Standard } \\
\text { Deviation } \\
\quad \text { of } \bar{E}\end{array}$ & $\stackrel{\operatorname{Gap}}{\bar{P}-\bar{E}}$ \\
\hline A. Tangibility & 5.94 & 0.93 & 6.51 & 0.63 & -0.57 \\
\hline $\begin{array}{l}\text { 1. Physical facilities of the pizzeria are } \\
\text { pleasant, attractive, and comfortable. }\end{array}$ & 5.29 & 0.76 & 6.54 & 0.64 & -1.25 \\
\hline $\begin{array}{l}\text { 2. The pizzeria offers a variety of } \\
\text { flavors. }\end{array}$ & 6.20 & 0.84 & 6.70 & 0.57 & -0.5 \\
\hline 3. Diversity of payment methods. & 6.43 & 0.68 & 6.33 & 0.69 & 0.1 \\
\hline 4. The pizzeria keeps its facilities clean. & 5.98 & 0.80 & 6.74 & 0.46 & -0.76 \\
\hline $\begin{array}{l}\text { 5. Appearance and professionalism of } \\
\text { employees. }\end{array}$ & 5.68 & 0.79 & 6.39 & 0.64 & -0.71 \\
\hline $\begin{array}{l}\text { 6. State of conservation of silverware } \\
\text { and dishware. }\end{array}$ & 5.75 & 0.83 & 6.78 & 0.50 & -1.03 \\
\hline $\begin{array}{l}\text { 7. Cleanliness of silverware and } \\
\text { dishware. }\end{array}$ & 6.37 & 0.58 & 6.79 & 0.45 & -0.42 \\
\hline 8. Organization and clarity of the menu. & 6.54 & 0.64 & 6.38 & 0.58 & 0.16 \\
\hline 9. Ease of reading the menu. & 6.32 & 0.74 & 6.23 & 0.62 & 0.09 \\
\hline 10. Location of the pizzeria. & 4.88 & 1.03 & 6.25 & 0.73 & -1.37 \\
\hline B. Reliability & 5.87 & 0.93 & 6.65 & 0.63 & -0.78 \\
\hline 11. Order delivery time. & 5.44 & 0.83 & 6.68 & 0.69 & -1.24 \\
\hline 12. Order mistake. & 6.30 & 0.82 & 6.62 & 0.58 & -0.32 \\
\hline C. Responsiveness & 6.14 & 0.70 & 6.43 & 0.63 & -0.29 \\
\hline $\begin{array}{l}\text { 13. Readiness to serve customers when } \\
\text { they arrive at the pizzeria. }\end{array}$ & 14.6 .35 & 15.0 .64 & 16. 6.44 & 17. 0.59 & 18. -0.09 \\
\hline 19. Presentation of problem solutions. & 6.13 & 0.65 & 6.32 & 0.64 & -0.19 \\
\hline 20. Employees available on time. & 6.19 & 0.72 & 6.47 & 0.57 & -0.28 \\
\hline 21. Attentive employees. & 5.98 & 0.76 & 6.57 & 0.53 & -0.59 \\
\hline 22. Speed in solving problems. & 6.02 & 0.65 & 6.34 & 0.76 & -0.32 \\
\hline D. Assurance & 5.89 & 0.87 & 6.61 & 0.63 & -0.72 \\
\hline $\begin{array}{l}\text { 23. Employees have a good degree of } \\
\text { knowledge about the service and its } \\
\text { elements. }\end{array}$ & 5.99 & 0.81 & 6.70 & 0.62 & -0.71 \\
\hline $\begin{array}{l}\text { 24. Employees demonstrate a good degree } \\
\text { of knowledge about the service and its } \\
\text { elements. }\end{array}$ & 5.78 & 0.91 & 6.52 & 0.62 & -0.74 \\
\hline E. Empathy & 6.31 & 0.72 & 6.62 & 0.60 & -0.31 \\
\hline $\begin{array}{l}\text { 25. Polite and cordial employees during } \\
\text { customer service. }\end{array}$ & 6.36 & 0.72 & 6.85 & 0.36 & -0.49 \\
\hline $\begin{array}{l}\text { 26. Employees attentive to customer } \\
\text { needs. }\end{array}$ & 5.95 & 0.70 & 6.30 & 0.70 & -0.35 \\
\hline 27. Convenient business hours. & 6.64 & 0.56 & 6.60 & 0.58 & 0.04 \\
\hline $\begin{array}{l}\text { 28. Employees demonstrate attention } \\
\text { during customer service. }\end{array}$ & 6.30 & 0.72 & 6.74 & 0.56 & -0.44 \\
\hline
\end{tabular}

Source: Prepared by the authors.

The results in Table 5 show that none of the analyzed dimensions satisfy the customers, because all of them presented negative values regarding the gap analysis. One of the causes of this non-compliance may be related to the lack of control and standardization of the service offered, since it is managed only by the owner, which makes it difficult to control the process. 
It is important to point out that a negative result in a certain dimension is dangerous for the company due to the inverse relationship existing between the gap and customer satisfaction, that is, the smaller the value of the gap in the dimension, the greater the customer's dissatisfaction. On the other hand, high values of the gap of dimensions reflect that the clients are satisfied with the service.

Among the criteria found with a higher degree of quality, items 8 -Organization and clarity of the menu, 3 - Diversity of payment methods, and 9 - Ease of reading the menu can be highlighted. On the other hand, among the points with negative perceptions are highlighted items 10 - Location of the pizzeria, 1 - Physical facilities of the pizzeria are pleasant, attractive, and comfortable, and 11 - Order Delivery time.

Among the items that are part of each dimension and that presented positive gaps can be highlighted in the Tangibility dimension items 3 - Diversity of payment methods with a value of 0.1, 8 - Organization and clarity of the menu with 0.16, and 9 - Ease of reading the menu with 0.09 . The items related to the menu presented positive notes because it had already been remade by a third party, after the request of the customers, who complained about the size of the font and disorganization. As for the payment, customers can make it by credit or debit card, in addition to cash, and this diversity may have contributed to the positive result present in this item.

In the Empathy dimension, there is item 22 - Convenient business hours with a value of 0.04 , with satisfactory results, which can be justified by the fact that the establishment opens its doors every day of the week, in a longer time interval than other companies in the same business.

In a general analysis of the results present in Table 5, it can be seen that of all the items analyzed, approximately $82.6 \%$ presented negative values, demonstrating here the need for much attention for improvements. For example, the Empathy dimension, which presented negative values, may mean that the company does not have a good relationship with customers, as employees are not acting in the best way to satisfy them.

The Reliability dimension obtained the most negative results, due to the fact that it presents only two topics and one of them, item 11 - Order delivery time, got a value of -1.24. This value has a difference in points of 0.95 compared to the lowest negative value obtained in the total analysis of the questionnaire, which is represented by item 13 - Readiness to serve customers when they arrive at the pizzeria. The negative values obtained in the Reliability 
dimension are real, as customers claim that the establishment did not deliver the service as promised.

Following the results obtained, there is the Assurance dimension, with the second largest negative gap index in the questionnaire, with an average value of -0.72 , which exposes the fragility of employees in knowing and demonstrating knowledge in relation to the service and its elements. Within this dimension, the element with the most negative result was 19 Employees demonstrate a good degree of knowledge about the service and its elements (0.74), while the best result was in item 18 - Employees have a good degree of knowledge about the service and its elements (-0.71).

The results for the Assurance dimension infer that employees present fragility when they have direct contact with customers, showing weakness, for example, in courtesy. For its items, it can be affirmed that the customers thought that the employees can even have knowledge about the service and its elements, but they don't show it delivering the necessary information for a good decision making.

Regarding the Responsiveness dimension, with an average value of (-0.29), item 16 Attentive employees presented the most negative value of the dimension (-0.59). According to the respondents, the employees are not always attentive and available for assistance. Item 13 Readiness to serve customers when they arrive at the pizzeria (-0.09) obtained the best result in the dimension, because the customers are received quickly when arriving at the establishment. In an analysis of the negative result of the dimension, it can be affirmed that the employees are not willing to help the customers, nor are they providing an agile service.

It is important to note that, even with all the gaps in the dimensions having negative values, the pizzeria does not necessarily have a precarious service. The negative values were derived from the high expectations of customers, as the average values were above 6 , and it can be said that the respondents were demanding in what concerns the importance of the questionnaire items. On the other hand, the perceptions of the dimensions varied between 5.87 and 6.31, which may infer that consumers agreed in part or in large part with the topics related to the service, based on the interpretation of the Likert Scale shown in section 2.2. Thus, given the values of perceptions, it can be said that the pizzeria does not offer a service of great concern about quality, as no result was below score 4, which represents disagreement with the service. 
High values of standard deviations mean that the data have a high degree of dispersion, as this index measures the variability of the values in relation to the average. From the analysis of the deviations shown in Table 5, it can be seen that in the column of perceptions the values were higher than those in expectations. The item with the greatest deviation for perception was 10 - Location of the pizzeria (1.03) and for the expectation was item 17 - Speed in solving problems (0.76).

Inferring acceptable results about the object under study by analyzing only the dimension can be considered a mistake, because the analysis may be flawed, demonstrating the need for further investigations based on the results obtained in the questionnaires. Thus, the quartile analysis suggested by Freitas et al. (2006) will be used to identify the items considered most critical, i.e., the items that should have a higher priority in the identification of failures that compromise the provision of the service. This analysis classifies items into four priority classes that are Critical, High, Moderate, and Low, in which each class is formed using the idea of quartile formation and contains $25 \%$ of each topic (FREITAS et al., 2006).

The questionnaire adapted for this work was composed of 23 items; therefore, $25 \%$ correspond to approximately six statements. Thus, the Critical quartile will be composed of five statements and the other three will be composed of six items, grouped in ascending order for expectation and gap, and in descending order for perception. For the expectation, high indices imply a higher degree of priority, and for perception and gap the opposite occurs: low indices imply a higher priority. Table 6 shows a better view of the items analyzed.

Table 6 - Priority Legend

\begin{tabular}{l|l}
\hline \multicolumn{1}{c}{ Priority } \\
\hline Critical \\
High \\
Moderate \\
Low
\end{tabular}

Source: Prepared by the authors.

Tables 7 and 8 present the results obtained with the quartile method in relation to customer expectations and perceptions. 
Table 7 - Prioritization of Items through the Quartile Method ( $\overline{\mathrm{E}})$ Regarding Expectation

\begin{tabular}{|c|c|c|c|c|c|c|c|c|c|c|c|c|}
\hline & \multicolumn{12}{|c|}{ Item Priority Rating - Expectation } \\
\hline Priority & \multicolumn{5}{|c|}{ Critical } & \multicolumn{7}{|c|}{ High } \\
\hline Item & 20 & 7 & 6 & 4 & 23 & 2 & 18 & 11 & 12 & 22 & \multicolumn{2}{|c|}{16} \\
\hline Grade & 6,85 & 6,79 & 6,78 & 6,74 & 6,74 & 6,70 & 6,70 & 6,68 & 6,62 & 6,60 & \multicolumn{2}{|c|}{6,57} \\
\hline & \multicolumn{12}{|c|}{ Item Priority Rating - Perception } \\
\hline Priority & \multicolumn{6}{|c|}{ Moderate } & \multicolumn{6}{|c|}{ Low } \\
\hline Item & 1 & 19 & 15 & 13 & 5 & 8 & 17 & 3 & 14 & 21 & 10 & 9 \\
\hline Grade & 6,54 & 6,52 & 6,47 & 6,44 & 6,39 & 6,38 & 6,34 & 6,33 & 6,32 & 6,30 & 6,25 & 6,23 \\
\hline
\end{tabular}

Source: Prepared by the authors.

In Table 7, it is possible to see that the items that presented the greatest expectation on the part of customers were: 20 - Polite and cordial employees during customer service, 7 Cleanliness of silverware and dishware, 6 - State of conservation of silverware and dishware, 4 - The pizzeria keeps the facilities clean, and 23 - Employees show attention during customer service. These aspects need more detail and attention from the pizza place. These statements belong to the dimensions Tangibility (4, 6 and 7) and Empathy (20 and 23).

Table 8 - Prioritization of Items through the Quartile Method ( $\bar{P}$ ) Regarding Perception

\begin{tabular}{|c|c|c|c|c|c|c|c|c|c|c|c|c|}
\hline & \multicolumn{12}{|c|}{ Item Priority Rating - Expectation } \\
\hline Priority & \multicolumn{5}{|c|}{ Critical } & \multicolumn{7}{|c|}{ High } \\
\hline Item & 10 & 1 & 11 & 5 & 6 & 19 & 21 & 4 & 16 & 18 & & 7 \\
\hline Grade & 4,88 & 5,29 & 5,44 & 5,68 & 5,75 & 5,78 & 5,95 & 5,98 & 5,98 & 5,99 & & 02 \\
\hline & \multicolumn{12}{|c|}{ Item Priority Rating - Perception } \\
\hline Priority & \multicolumn{6}{|c|}{ Moderate } & \multicolumn{6}{|c|}{ Low } \\
\hline Item & 14 & 15 & 2 & 12 & 23 & 9 & 13 & 20 & 7 & 3 & 8 & 22 \\
\hline Grade & 6,13 & 6,19 & 6,20 & 6,30 & 6,30 & 6,32 & 6,35 & 6,36 & 6,37 & 6,43 & 6,54 & 6,64 \\
\hline
\end{tabular}

Source: Prepared by the authors.

From the analysis of Table 8 , it can be seen that the items in which the pizzeria presented the worst performance according to the customers' point of view were: 10 Location of the pizzeria, 1 - Physical facilities of the pizzeria are pleasant, attractive, and comfortable, 11 - Order delivery time, 5 - Appearance and professionalism of employees, and 6 - State of conservation of silverware and dishware. Among them, only item 6 is also present as critical in expectations. The topics with critical priority are linked to the dimensions Tangibility (1, 5, 6 and 10) and Reliability (11).

From the observation of the two previous Tables, it can be seen that item 6 - State of conservation of silverware and dishware presents critical priority in expectation and does not present a good perception by customers. It is also possible to notice that the customers end up 
waiting a time above average after the order, because the item 11 - Order delivery time presents high priority to the expectation and critical priority to the perception. After the analysis in relation to the expectation and perception of the customers, it is necessary to make an evaluation in relation to the gaps, that is, if what is perceived by the customers complements what is expected by them and Table 9 was structured to accomplish this.

Table 9 - Prioritization of Items through the Quartile Method $(\bar{G})$ Regarding Perception Gaps

\begin{tabular}{|c|c|c|c|c|c|c|c|c|c|c|c|c|}
\hline & \multicolumn{12}{|c|}{ Item Priority Rating - Expectation } \\
\hline Priority & \multicolumn{5}{|c|}{ Critical } & \multicolumn{7}{|c|}{ High } \\
\hline Item & 10 & 1 & 11 & 6 & 4 & \multicolumn{3}{|c|}{19} & 18 & 16 & 2 & 20 \\
\hline Grade & $-1,37$ & $-1,25$ & $-1,24$ & $-1,03$ & $-0,76$ & & 74 & $-0,71$ & $-0,71$ & $-0,59$ & $-0,50$ & $-0,49$ \\
\hline & \multicolumn{12}{|c|}{ Classificação de Prioridade dos Itens - Gaps } \\
\hline Priority & \multicolumn{6}{|c|}{ Moderate } & \multicolumn{6}{|c|}{ Low } \\
\hline Item & 23 & 7 & 21 & 12 & 17 & 15 & 14 & 13 & 22 & 9 & 3 & 8 \\
\hline Grade & $-0,44$ & $-0,42$ & $-0,35$ & $-0,32$ & $-0,32$ & $-0,28$ & $-0,19$ & $-0,09$ & 0,04 & 0,09 & 0,1 & 0,16 \\
\hline
\end{tabular}

Source: Prepared by the authors.

From the data presented in Table 9, it is clear that the topics 10 - Location of the pizzeria, 1 - Physical facilities of the pizzeria are pleasant, attractive, and comfortable, 11 Order delivery time, 6 - State of conservation of silverware and dishware, and 4 - The pizzeria keeps its facilities clean obtained critical priority, which implies an urgent application of improvements. It is also noted that items 4 and 6 appeared in the critical part of Table 7 of expectations and items $1,6,10$, and 11 appeared in the critical part of Table 8 of perceptions. The common fact of the critical parts of the gaps and expectations means that items 4 and 6 were considered to be of great importance to customers. On the other hand, the presence of items $1,6,10$, and 11 both in the critical parts of gaps and perceptions infer that the activities presented by the pizzeria for these items can be considered undesirable and unsatisfactory.

After observing Table 9 on the priority of the results of the gaps, more visits were made to the establishment to discuss the possible causes of the bad results and propose a set of possible improvements for the most serious topics, such as, for example, for the most negative item in the critical rating: 10 - Location of the pizzeria. It was mentioned by the manager and the clients that this undesirable result comes from the fact that the establishment is located in a neighborhood with high crime rates and by the fact that its location is difficult to access. 
The solution in relation to the high crime rate would be a radical change, the migration of the enterprise to another neighborhood considered less violent, because the decrease of such rate does not depend on the manager. As a milder measure, compared to the change of location that implies high costs, it is proposed to hire private security to provide a safer climate for customers. It would also contribute to the security of the establishment to implement an effective security management, using basic equipment and services such as monitoring cameras connected to a central and even patrol services in the vicinity of the site, paying greater attention to vulnerable points.

In terms of accessibility, the pizzeria has an outsourced marketing service for the divulgation of only products and promotions. It was agreed that the outsourced company would also begin to divulge the location more frequently, displaying the map of the region and defining points of reference to help customers to arrive easily at the establishment.

The next critical item was 1 - Physical facilities of the pizzeria are pleasant, attractive, and comfortable. During the visits it was noticed that the appearance of the pizzeria does not match the market demands, because it does not present an attractive decoration. It was also noticed that tables and chairs are old and do not present a good state of conservation and comfort. Therefore, it is recommended that the pizzeria should undergo punctual refurbishment and that a professional with knowledge in decoration be hired to make it more modern, as well as the acquisition of more comfortable furniture for the customers' comfort. The modification of the layout of the place was also discussed so that unpleasant areas are not near the customers' seats, for example, it would be very frustrating for customers to have the entrance to the restrooms close their tables.

The third item considered critical was 11 -Order delivery time, which needs urgent improvement because, as seen in section 4.1, it was responsible for the low reliability of the dimension in which it is. It was observed that when customers placed an order, the waiters registered it manually, passed it on to the receptionists and only then the order arrived in the kitchen for those responsible for its preparation.

From the analysis of this process, it was noticed that time was wasted as more than two people were used to make the transition between the customer and the person responsible for the preparation. As a suggestion, the use of technology is recommended by implementing a data center that will be responsible for registering orders from each table on a server, eliminating the use of paper orders. The system will be completely automated, with all 
products registered, in which the waiter creates the order through a tablet and immediately the customer's request will be sent to the kitchen. In addition, the hiring of another temporary pizza chef for days with high demand was suggested, as the order delivery time also depends on the time of preparing the pizza.

The fourth item considered critical was 6 - State of conservation of silverware and dishware. As well as the tables and chairs, the solution for this topic is the acquisition of new items, modern and easy to handle so that customers can handle food in an agile, easy, and pleasant way. Also, the maintenance of the items is of fundamental importance for their conservation, so it is desirable that employees pay attention to the cleaning of all utensils constantly.

The next item highlighted to be improved is 4 - The pizzeria keeps its facilities clean. During the visits, it was not noticed any dirtiness in the place, however it is noticed that there is not a person hired to make the daily cleaning of the establishment. What is found is that this service was performed by some employees in addition to their usual functions for which they were hired (customer service by waiters, for example).

It should also be noted that the cleaning of the place is only carried out at the end of the daily shift, that is, when employees are already exhausted from their daily activities, which can contribute to the execution of a service with low quality. Thus, this work proposed the hiring of outsourced staff to perform this service daily in the establishment, keeping it always clean and ready to receive its customers, especially before the opening of the customer service venue.

After presenting solutions to improve performance in the gaps considered critical, it was discussed the high number of customers who attend the pizzeria per day versus the results obtained. It was argued that the price of the products offered combined with excellent marketing is responsible for the high number of customers. In other words, the establishment offers a healthy cost-benefit ratio for customers, with prices below the average of its competitors. In addition, the high demand of the establishment can also be justified by the offer of the rotation service (all-you-can-eat) on some days of the week.

Finally, it was suggested to the manager that a new management method should be applied, based on cost reduction and focusing on the quality of the services provided to the customers. This new model will be based on the principle of continuous improvement, adopting practices such as the culture of " $5 \mathrm{~S}$ " and kaizen, and these practices can enable the 
company to carry out more objective and organized activities in order to improve performance.

\section{CONCLUSION}

At the end of the research, it appears that its main objective was achieved, since a set of solutions for the analyzed services was proposed, which are possible thanks to the application and adaptation of the SERVQUAL model, emphasizing here another success of its application in the analysis of the quality of the most diverse types of services.

In sequence, it is also perceived the effectiveness of using Cronbach's $\alpha$ to analyze the reliability of the restructured questionnaire, in such a way that all dimensions were verified. In this context, it was observed that most dimensions presented good reliability indexes, with the exception of the Reliability dimension, which can be justified by the fact that the dimension in question has only two elements of analysis.

With the use of Quartile Analysis, it is possible to separate the analyzed items by priority categories for the execution of improvements in the system. This information can be useful for the management of the pizzeria, especially in supporting the development of planned strategies to improve customer satisfaction. And in a general analysis, it appears that there were few items that obtained positive results in the relational analysis between expectation and perception, being able to highlight only items related to the menu, payment methods, and business hours of the pizzeria, while items related to cleanliness of the place, silverware and dishware, personalized service, order delivery time, and location of the establishment presented low quality levels, requiring immediate interventions based, for example, on the proposed solutions.

As the item related to the order delivery time was one of the factors responsible for the low reliability, it was decided that the improvements would start with this topic within the organization, that is, it became a priority goal. Proposals for improvements were also presented not only for this issue, but for all elements whose gaps remained in the critical quartile. The solutions were suggested for the minimization and/or correction of the detected points.

It is also important to point out that changes in the organizational culture are necessary, especially to make more visible and collaborative the management of the business, which today is only in the hands of the owner. What is meant here is to know how to listen, 
that is, to seek from the employees points where improvements can be implemented, thus contributing to the enrichment of labor relations, as well as the motivation of the entire team.

Regarding future work, this research highlights the company's reanalysis in a near future, to feel the effects of the proposed solutions, as well as the pace of their implementation. Thus, applying SERVQUAL again, as well as other analysis methods such as SERVPERF (the performance component of SERVQUAL), are plausible future actions. It is also proposed to apply more relational statistical analysis, such as multi-criteria or varied analysis, to better understand the results obtained and their effects on the processes, thus seeking to highlight which items under analysis contribute most to the customer satisfaction.

\section{References}

ABIA - Associação Brasileira das Indústrias de Alimentação. Relatório Anual 2015. Disponível em: 〈http://www.abia.org.br/vsn/anexos/relatorioanualABIA2015.pdf>. Acesso em 10 mar. 2018.

ANVISA - Agência Nacional de Vigilância Sanitária. Disponível em <http://bvsms.saude.gov.br/bvs/saudelegis/anvisa/2004/res0216_15_09_2004.html>. Acesso em 10 mar. 2018.

BARBETTA, P.A. - Estatística aplicada às ciências sociais. Ed. UFSC, 2008.

CERVO, A. L.; BERVAIN, P. A.; SILVA, R. Metodologia Científica. 6 Ed. São Paulo: Pearson Prentice Hall, 2007.

FIGUEIREDO, V. F.; COSTA NETO, P. L. O. Implantação do HACCP na indústria de alimentos. Gestão e Produção. São Carlos. v. 8, n. 1, p. 100- 111, abr. 2001.

FILHO, M. P. Aplicação do Modelo de Avaliação da Qualidade de Serviço SERVQUAL em Curso Superior de Tecnologia de Gestão de Produção Industrial. 2009. 93 f. Dissertação (Mestrado em Engenharia de Produção) - Universidade Federal de Santa Catarina. Florianópolis, 2009.

FITZSIMMONS, J. A.; FITZSIMMONS M. J. Administração de serviços: operações, estratégia e tecnologia da informação, 4 ed.. Porto Alegre: Bookman, 2005.

FREITAS, A.L.P.; MANHÃES, N.R.C.; COZENDEY, M.Y. Emprego do SERVQUAL na avaliação da Qualidade de Serviços de Tecnologia da Informação: uma análise experimental. 26, 2006. Anais... ENEGEP, p.1-8, 2006.

GIANESI, I.G.N.; CORRÊA, H.L. Administração estratégica em serviços: operações para a satisfação do cliente. São Paulo: Atlas, 2004. 
GIL, A. C. Como Elaborar Projetos de Pesquisa. 4ed. São Paulo: Atlas, 2002.

GIL, A.C. Como Elaborar Projetos de Pesquisa. 5.ed. São Paulo: Atlas, 2010.

GONÇALVES, T.J.M; BELDERRAIN, M.C.N. Avaliação da qualidade em lan houses através da adaptação do instrumento servqual. Revista Produção Online, Florianópolis, SC, v.12, n.1, p. 248-268, 2012.

LIKERT, R. A technique for the measurement of attitudes. Archives of Psychology. v. 22, n. 140, p. 44-53, 1932.

LOVELOCK, C.; WRIGHT L. Serviços: marketing e gestão. São Paulo: Saraiva, 2002.

MALHOTRA, N K. Pesquisa de Marketing. Artmed Bookman. 2008.

MONTEIRO, S. B. S. Coordenação da qualidade em cadeias de produção de alimentos: práticas adotadas por grandes empresas. 2005. 217 f. Tese (Doutorado em Engenharia da Produção) - Universidade Federal de São Carlos. São Carlos, 2005.

MOURA, T.C.; ALLIPRANDINI, D.H. Determinantes da qualidade em serviços de alimentação: O caso das empresas de refeições coletivas. In: Encontro Nacional de Engenharia de Produção, 24., 2004. Anais... Florianópolis: Associação Brasileira de Engenharia de Produção, p. 1884-1891, 2004.

OLIVEIRA, O.J.; FERREIRA, E.C. Adaptação e aplicação da escala SERVQUAL na educação superior. Revista GEPROS, v. 3, n. 3, p. 22 - 52008.

PARASURAMAN, A.; ZEITHMAL, V. A; BERRY, L. L. A conceptual model of service quality of and its implication for future research. Jornal of Marketing, v.49, p. 41-50, fall 1985.

RICHARDS, N.S.P.S. Segurança Alimentar: como prevenir contaminações na indústria, Revista Food Ingredients - Pesquisa e Dessenvolvimento na Indústria de Alimentos e Bebidas, edição 18, maio/jun.2005.

SANTOS, A. B.; ANTONELLI, S. C. Aplicação da abordagem estatística no contexto da gestão da qualidade: um survey com indústrias de alimentos de São Paulo. Gestão e Produção. São Carlos. v. 18, n. 3, p. 509-524. 2011.

SCALCO, A.R.; TOLEDO, J. C. Gestão da qualidade em laticínios do estado de São Paulo: situação atual e recomendações. Revista de Administração, São Paulo, v. 37, n. 2, p. 17-25, 2002.

SCHLÜTER, R.G. Turismo e Gastronomia. São Paulo: Aleph, 2003.

SCHNEIDER, B.; WHITE, S. Service quality: Research perspectives. California: Sage Publications, 2004. 
SEBRAE - Serviço Brasileiro de Apoio às Micro e Pequenas Empresas - Como montar uma pizzaria. Disponível em <http://www.sebrae.com.br/sites/PortalSebrae/ufs/mg/artigos/comoabrir-uma-pizzaria-em-minas-gerais,43c9d665675c9410VgnVCM1000003b74010aRCRD>. Acesso em 10 mar. 2018.

SPERS, E.E. Mecanismos de Regulação da Qualidade e Segurança dos Alimentos. 2003. 136p.Tese (Doutorado) - Universidade Estadual de Campinas. Campinas, SP, 2003.

TURRIONI, J. B.; MELLO, C. H. P. M. Metodologia de pesquisa em engenharia de produção. UNIFEI, 2012.

WILSON, A., ZEITHMAL, V.A., BITNER, M.L., GREMLER, D.D. - Service Marketing Integrating Customer Focus Across the Firm. 2. Ed. Berkshire: McGraw-Hill, 2012. 